\title{
Recycling of Food Waste into Chemical Building Blocks
}

\author{
Vinod Kumar*, Philip Longhurst
}

Centre for Bioenergy and Resource Management (CBRM), School of Water, Energy and Environment, Cranfield University, Bedford MK43 0AL, United Kingdom

\section{*Corresponding author}

Tel.: +441234754786; E-mail address: Vinod.Kumar@cranfield.ac.uk

\begin{abstract}
Enormous quantities of food waste (FW) arise from global production. Roughly, one third of all food for human consumption is wasted resulting in huge costs to the world economy alongside significant environmental problems. FW is a potential reservoir of functionalized molecules, i.e. carbohydrates, proteins and lipids that can be recovered, concentrated and transformed into high value products. Conversion of renewable carbon from FW to building block chemicals can also more profitable than conventional processing methods. Recent studies have used microbial routes to recover value from FW into a number of chemical building blocks. Recycling FW into valuable chemicals directly contributes to the transition from current fossil fuel-based economies to a bioeconomy and reduced waste society. This paper reviews the potential for using FW and focuses on recent updates in second-generation valorisation methods where the bioproduction of chemical building blocks uses FW as a feedstock.
\end{abstract}

Key words: Food waste; Chemical building blocks; Succinic acid; Lactic acid; 2,3Butanediol; Ethanol; n-Butanol 
Need for waste biorefineries: International priorities to reduce fossil fuel emissions, alongside rising prices for oil derivatives are resulting in significant interest in the production of chemical building blocks from renewable sources $[1,2]$. The biorefinery concept has the potential to contribute to reducing international dependency on petroleum-based industries globally. Biorefineries are integrated complexes producing marketable products and energy from the processing of biomass. Analogous to petroleum refineries, first generation biorefineries generate biofuels and biochemicals from edible sources, e.g. starch, sugar, corn, animal fats and vegetable oils. These processes are efficient, well established but are part of the food versus fuel debate. However, the high cost of fermentable sugars limits the scope of bulk chemicals manufactured economically. In addition, use of these substrates as production feedstocks is unsustainable as they are essential components within the food chain. To ensure the long-term feasibility of biorefineries, development efforts are focussing on alternative technologies capable of producing fuels and chemicals from a wide array of non-edible, agroindustrial by-products most commonly available as wastes [3, 4]. This biorefinery concept enables the valorisation of discarded substrates into feedstocks producing high value from wastes.

Food waste and more circular economies: a definition of food waste (FW) is the unconsumed, discarded or lost produce arising from any of the four stages of the food supply chain from; agriculture \& processing, handling \& storage, the retail market, and final consumption. Current estimates are that between one-third and a half of all food produced worldwide, i.e. approx. 1.3 billion tonnes per year is wasted with a total cost to the world economy of about $\$ 750$ billion [5, 6]. In the UK alone, FW was more than 14 million tonnes in 2013, the highest wastage rate in Europe [7, 8]. In addition to being a significant loss of valuable materials, these enormous quantities result in serious management problems, both economically and environmentally. Emission calculations indicate losses of two tonnes of 
carbon dioxide per tonne of waste. FW spoils quickly due to its high nutritional and water content. This bacterial contamination provides the basis for first generation valorisation technologies including; anaerobic digestion, composting, incineration and animal feed production with residues disposed to landfills. Despite the value gained in producing energy and soil amendments from these methods, the high quantity of FW has the potential feedstock for global bioproduction of large quantities of high value chemicals. Indeed, the conversion of FW to building block chemicals can be more profitable than conventional processing methods [9]. FW is attractive in terms of its nutrient content, i.e. 30-60\% starch, 5-10\% proteins and $10-40 \%$ lipids. Notably, the sugar content is high in value for microbial fermentation in comparison to other bulk, crude, or renewable sources such as recalcitrant lignocellulose wastes [10]. Conversion processes, shown in Figure 1, unlock this huge potential from FW resulting in a spectrum of commodity chemicals. This integration of renewable carbon from FW within a biorefinery relies in low cost feedstocks with a reduced carbon footprint. The combination of waste recycling, production of valuable chemicals and a reduced carbon footprint aligns well with sustainable development goals and transition from a fossil fuel-based economy to a bioeconomy and low-waste society.

Bioconversion of FW into commercially important chemicals: Sourcing cheap and easily fermentable feedstocks is a major challenge for bio-based industries. FW is rich in functionalized molecules which can be recovered, concentrated and transformed into high value products [11-13], see Figure 2. The reutilization of FW as feedstocks for the bioproduction for chemicals is evident in recent innovative work where selected chemical building blocks have been successfully synthesized using FW as substrate, see Table 1. Table

2 shows the maximum theoretical potential of chemical building blocks from FW. Calculations have been determined for the sugar concentration in FW hydrolysate, reported 
by Pleissner et al. [14]. The following sections discuss recent updates and the potential for bioproduction from FW of these chemical building blocks.

Succinic acid: According to US Department of Energy, succinic acid is a top platform chemical which can be produced from biomass. This platform chemical has multiple practical applications including synthesis of 1,4-butanediol, tetrahydrofuran, gamma-butyrolactone, plus as a monomer for some biodegradable polymers [15]. Biomolecules present in FW are in the form of macromolecules such as starch, cellulose, proteins and lipids etc. These need to be hydrolysed into useable forms to enable microbial growth for biochemical production. Zhang et al. [16] and Leung et al. [17] employed bakery wastes, e.g. cake, pastries and bread for microbiological succinic acid production by Actinobacillus succinogenes. The starch and proteins molecules in bakery and bread waste were broken down into glucose and amino acids using fungal enzymes by Aspergillus awamori and Aspergillus oryzae. The hydrolysate from fungal treatment was rich in sugars and free amino nitrogen with sufficient nutrients to support the growth of $A$. succinogenes. No additional supplements were required. The titre of succinic acid accumulated using cake, pastry and bread wastes were $24.8,31.7$ and $47.3 \mathrm{~g} / \mathrm{L}$ with a yield of $0.80,0.67$ and $1.16 \mathrm{~g} / \mathrm{g}$ sugars, respectively. Downstream processing was also conducted to recover succinic acid crystals with a purity level of $96-98 \%$ in the case of bakery waste. In their latest work, they made use of fruit and vegetable waste (apples, pears, orange, potatoes, cabbage, lettuce and taros) hydrolysate as feedstock and a massive succinic acid titre of $140.6 \mathrm{~g} / \mathrm{L}$ was accumulated by oleaginous yeast Yarrowia lipolytica using this hydrolysate [18].

Lactic acid: Lactic acid is a commercially important chemical with wide ranging applications in the food, chemical, cosmetic and pharmaceutical industries. Lactic acid is a monomer that can be polymerized to yield the biodegradable plastics, polylactic acid (PLA) and poly(3-hydroxybutyrate-co-lactate). Unlike the chemical route, microbial fermentation 
can yield optically pure isomers, D- and L-lactic acid. Currently, nearly all commercial lactic acid comes from microbial fermentation [19]. Kwan et al. [20] used the same strategy referred to above to produce lactic acid from mixed food leftovers of rice, noodles, meat and vegetables as well as bakery wastes including, unsold products such as cakes, breads and pastries. The fermentation of mixed food and bakery waste hydrolysate by Lactobacillus casei Shirota resulted in 94.0 and $82.6 \mathrm{~g} / \mathrm{L}$ lactic acid with a high productivity of 2.61 and $2.50 \mathrm{~g} / \mathrm{L}$. h, respectively. The yield was the same $(0.94 \mathrm{~g} / \mathrm{g})$ for both hydrolysates.

2,3-butanediol (BDO): BDO is a promising compound both as a platform chemical and as a liquid fuel. BDO has many applications in the pharmaceutical, biomedical, and other chemical industries for the production of printing inks, perfumes, fumigants, spandex, moistening and softening agents, and plasticizers, e.g., cellulose nitrate, polyvinyl chloride and polyacrylates [21]. BDO is also used as an antifreezing agent, and octane booster for petrol as is; or it can be converted to useful derivatives such as 1,3-butadiene, diacetyl and methyl ethyl ketone. In recent work, BDO was manufactured from fruit, i.e. plums, apples and pears, and mixed with vegetable wastes containing mainly broccoli (80\%) using Enterobacter ludwigii [22]. The sugars, glucose, fructose and sucrose present in the fruit extract were fermented to BDO. The fed-batch cultivations of E. ludwidgii resulted in a BDO concentration of $50 \mathrm{~g} / \mathrm{L}$ with a yield and productivity of $0.4 \mathrm{~g} / \mathrm{g}$ and $0.41 \mathrm{~g} / \mathrm{L}$. h, respectively. The vegetable waste was pre-treated with sulphuric acid (3\%) to extract the sugars; glucose, fructose, xylose, galactose and arabinose, from the hemicellulosic fraction. The BDO titre obtained from mixed vegetable waste hydrolysate was $17.6 \mathrm{~g} / \mathrm{L}$ with a conversion yield of $0.32 \mathrm{~g} / \mathrm{g}$ and productivity of $0.39 \mathrm{~g} / \mathrm{L} . \mathrm{h}$.

Ethanol: Ethanol is a renewable energy source and widely used as a fuel additive for partial gasoline replacement. Commercial ethanol is produced currently from fermenting sugar and starch. USA and Brazil are the major producers of ethanol in the world. Corn is the dominant 
feedstock used for production in USA and sugarcane in Brazil. Ethanol is by far the most significant biofuel in the USA, accounting for all biofuel production in 2012. In recent times a number of reports on ethanol production from FW have been published. Huang et al. [23] investigated the feasibility of producing ethanol from $\mathrm{FW}$ at high solids content, i.e. 35\%, w/w. FW was collected from a food retail store in Illinois, USA that contained mainly mashed potatoes, sweet corn and white bread. Conventional fermentation resulted in accumulation of $144 \mathrm{~g} / \mathrm{L}$. A vacuum recovery system was employed to eliminate product inhibition and thus complete consumption of glucose. Ethanol yield for vacuum and conventional fermentation was found to be $358 \mathrm{~g} / \mathrm{kg}$ and $327 \mathrm{~g} / \mathrm{kg}$ of FW (dry basis), respectively. Kiran and Liu [24] attempted ethanol production from waste cake. The fungal mash rich in hydrolytic enzymes was employed for obtaining glucose $(127 \mathrm{~g} / \mathrm{L})$ and free amino nitrogen $(1.8 \mathrm{~g} / \mathrm{L})$ from $\mathrm{FW}$. Use of a hydrolysed solution as sole fermentation feedstock resulted in $58 \mathrm{~g} / \mathrm{L}$ of ethanol with a yield of $0.5 \mathrm{~g} / \mathrm{g}$ in $32 \mathrm{~h}$.

n-Butanol: 1-Butanol or n-butanol is an attractive molecule for its multiple uses as a solvent, intermediate within the chemical industry, as well as a fuel. It also has a low vapour pressure and gasoline-like octane rating which allows it to be blended with gasoline or used as a pure fuel without modification in some vehicle engines [25]. FW contains significant amounts of sugars and starch, which can be easily metabolized into n-butanol by Clostridia, a wellknown organisms for $\mathrm{ABE}$ fermentation. FW has also been examined as a feedstock for acetone-butanol-ethanol (ABE) fermentation with butanol as the main product. Bioconversion of FW, i.e. potatoes, sweet corn and white bread, by Clostridium beijerinckii accumulated $18.9 \mathrm{~g} / \mathrm{L} \mathrm{ABE}$ solvents with a productivity of $0.46 \mathrm{~g} / \mathrm{L} . \mathrm{h}$ and yield of $0.38 \mathrm{~g} / \mathrm{g}$ from $81 \mathrm{~g} / \mathrm{L}$ FW containing an equivalent glucose of $60.1 \mathrm{~g} / \mathrm{L}$. On the other hand, $14.2 \mathrm{~g} / \mathrm{L}$ of ABE was produced from $40.5 \mathrm{~g} / \mathrm{L}$ in control fermentation with a productivity and yield of $0.22 \mathrm{~g} / \mathrm{L} . \mathrm{h}$ and $0.35 \mathrm{~g} / \mathrm{g}$, respectively [26]. Similar results were obtained by Ujor et al. [27] 
where batch $\mathrm{ABE}$ fermentations were carried out by $C$. beijerinckii using inedible dough, breadings, and batter liquid as substrates, see Table 1. ABE fermentation of FW has several advantages including lower feedstock cost, and higher productivity in comparison to costly glucose.

Future outlook: In the last two decades, the bio-based production of chemicals and polymers from renewable sources has received notable attention. The cost of feedstock is a major hurdle for the fermentative production of chemicals, accounting for up to $70 \%$ of total costs and severely influencing commercial viability. The majority of FWs are carbohydrate rich and thus a feasible feedstock alternative for fermentative production of chemicals. FW has several advantages in comparison to lignocellulosic biomass (LCB). Most FW contains significant amounts of sugars and starch, which can be easily valorised to high value products by the majority of industrially attractive microbes. In contrast, LCB requires harsh pretreatments with a large investment in energy. In addition to sugars, FW contains functionalized molecules, i.e. proteins, fatty acids, minerals, unlike LCB. These support microbial growth eventually leading to improved metabolite production rates. The fermentative production of chemicals from most of FW does not require supplementation of expensive hydrolytic enzymes, i.e. the most expensive pre-treatment step. This is a significant economic advantage. Further, the energy content and global abundance of starchy FW makes them ideal for use as potential feedstocks for bioproduction. Recent FW valorisation studies opens a number of avenues giving hope for the bulk production of bio-based products including chemicals, fuels, bioactive compounds, biodegradable plastics, enzymes and many other molecules. The concept of the FW-based biorefinery is still in its infancy and many more efforts are required before it is evident in commercialization.

Conclusion: The generation of food waste is inevitable. This has the potential to cause significant environmental damage including the formation and emission of greenhouse gases, 
as well as ground water contamination. Thus, developing more sustainable solutions for FW management is a large-scale challenge for society. However, FW is a renewable bioresource with potential to produce valuable chemicals at industrial scale, i.e. a raw material for biorefineries. The profitability of chemicals and biofuels produced from FW has the potential to stimulate investment in biorefinery chains increasing the likelihood that $\mathrm{FW}$ processing will move away from traditional waste management processes. The development of risk assessment methods and legislation will need to match these changes in order to stimulate and promote production of new chemical building block markets from FW biorefineries. This development will enable effective exploitation of $\mathrm{FW}$ with the potential for positive contributions to renewable energy, more sustainable production of raw materials, economic value and reductions in environmental impact. 


\section{References}

1. Octave S, Thomas D: Biorefinery: Toward an industrial metabolism. Biochimie 2009, 91:659-664.

2. Akhtar J, Idris A, Aziz RA: Recent advances in production of succinic acid from lignocellulosic biomass. Appl Microbiol Biotechnol 2014, 98:987-1000.

3. Naik SN, Goud VV, Rout PK, Dalai AK: Production of first and second generation biofuels: A comprehensive review. Renew Sust Energ Rev 2010, 14:578-597.

4. Menon V, Rao M: Trends in bioconversion of lignocellulose: Biofuels, platform chemicals \& biorefinery concept. Prog Energy Combust Sci 2012, 38:522-550.

5. Paritosh K, Kushwaha SK, Yadav M, Pareek N, Chawade A, Vivekanand V: FW to energy: an overview of sustainable approaches for FW management and nutrient recycling. BioMed Res Int 2017, doi.org/10.1155/2017/2370927.

6. Gustavsson J, Cederberg C, Sonesson U, van Otterdijk R, Meybeck A: Global food losses and FW: Extent, causes and prevention. 2011, FAO, Rome.

7. WRAP: Food Waste Reduction. 2013, http://www.wrap.org.uk/food-wastereduction.

8. Girotto F, Alibardi A, Cossu R: Food waste generation and industrial uses: a review. Waste Manag 2015, 45:32-41.

9. Tuck CO, Pérez E, Horváth IT, Sheldon R, Poliakoff M: Valorization of biomass: deriving more value from waste. Science 2012, 337:695-699.

10. Pleissner D, Lin CSK: Valorisation of food waste in biotechnological processes. Sust Chem Process 2013, 1(1):1-6.

11. Lin CSK, Pfaltzgraff LA, Herrero-Davila L, Mubofu EB, Abderrahim S, Clark JH, Thankappan S: Food waste as a valuable resource for the production of chemicals, materials and fuels. Current situation and global perspective. Energy Environ Sci 2013, 6:426-464.

12. Lin CSK, Koutinas AA, Stamatelatou K, Mubofu EB, Matharu AS, Kopsahelis N, Pfaltzgraff LA, Clark JH, Papanikolaou S, Kwan TH, Luque R: Current and future trends in 
food waste valorization for the production of chemicals, materials and fuels: a global perspective. Biofuels Bioprod Biorefin 2014, 8:686-715.

13. Ong KL, Kaur G, Pensupa N, Uisan K, Lin CSK: Trends in food waste valorization for the production of chemicals, materials and fuels: Case study South and Southeast Asia. Bioresour Technol 2017, http://dx.doi.org/10.1016/j.biortech.2017.06.076.

14. Pleissner D, Kwan TH, Lin CSK: Fungal hydrolysis in submerged fermentation for food waste treatment and fermentation feedstock preparation. Bioresour Technol 2014, 158:48-54.

15. Cheng KK, Zhao XB, Zeng J, Zhang JA: Biotechnological production of succinatecurrent state and perspectives. Biofuels Bioproducts and Biorefining 2012, 6:302-318.

16*. Zhang AY, Sun Z, Leung CCJ, Han W, Lau KY, Li M, Lin CSK: Valorisation of bakery waste for succinic acid production. Green Chem 2013, 15 (3):690-695.

Demonstrates succinic acid production from bakery waste as well as high level purification of crystals of succinic acid from fermentation broth.

17. Leung CCJ, Cheung ASY, Zhang AYZ, Lam KF and Lin CSK: Utilisation of waste bread for fermentative succinic acid production. Biochem Eng J 2012, 65(0):10-15.

18*. Li C, Yang X, Gao S, Chuh AH, Lin CSK: Hydrolysis of fruit and vegetable waste for efficient succinic acid production with engineered Yarrowia lipolytica: J Cleaner Prod 2018, 179:151-159.

Novel use of fruit and vegetable waste as feedstock for the sustainable production of succinic acid as a platform chemical in food waste biorefinery.

19. Abdel-Rahman MA, Tashiro Y, Sonomoto K: Recent advances in lactic acid production by microbial fermentation processes. Biotechnol Adv 2013, 31:877-902.

20*. Kwan HK, Hu Y, Lin CSK: Valorisation of food waste via fungal hydrolysis and lactic acid fermentation with Lactobacillus casei Shirota. Bioresour Technol 2016, 217:129-136.

A high level production of lactic acid using mixed food and bakery waste.

21. Ji X-J, Huang H, Ouyang P-K: Microbial 2,3-butanediol production: A state-of-the-art review. Biotechnol Adv 2011, 29:351-364.

22*. Liakou V, Pateraki C, Palaiogeorgou A-M, Kopsahelis N, de Castro AM, Freire DMG, Nychas G-J E, Papanikolaou S, Koutinas A: Valorisation of fruit and vegetable waste from open markets for the production of 2,3-butanediol. Food Bioprod Process 2017, https://doi.org/10.1016/j.fbp.2017.10.004.

The efficient bioconversion of fruit and vegetable waste from open market as fermentation feedstock to 2, 3-butanediol and a decentralized approach for recycling of food waste. 
23. Huang H, Qureshi N, Chen M-H, Liu W, Singh V: Ethanol production from food waste at high solids content with vacuum recovery technology. J Agric Food Chem 2015, 63:2760-2766.

Food wastes (corn, potatoes, and pasta) were converted to ethanol and a vacuum recovery system was employed to remove yeast inhibition caused by ethanol which enabled complete utilization of glucose.

24*. Kiran EU, Liu Y: Bioethanol production from mixed food waste by an effective enzymatic pretreatment. Fuel 2015, 159:463-469.

In this work, highly efficient fungal mash rich in various hydrolytic enzymes was employed for pre-treatment of mixed food waste and hydrolysate was used as feedstock for ethanol production. The study demonstrated that food waste can be successfully used as the nutrient-complete hydrolysates for the fermentative production of ethanol.

25. Zheng J, Tashiro Y,Wang Q, Sonomoto $\mathrm{K}$ :Recent advances to improve fermentative butanol production: Genetic engineering and fermentation technology. J Biosci Bioeng 2015, 119(1):1-9.

26*. Huang H, Singh V, Qureshi N: Butanol production from FW: a novel process for producing sustainable energy and reducing environmental pollution. Biotechnol Biofuels 2015, 8 (1):147.

The fermentative production of n-butanol was carried out using food waste. The fermentation was coupled with in situ removal using novel vacuum stripping technology to reduce n-butanol concentration in culture broth to alleviate its toxic effects. It was demonstrated that food waste is a superior feedstock for producing butanol in comparison to costly glucose.

27*. Ujor V, Bharathidasan AK, Cornish K, Ezeji TC: Feasibility of producing butanol from industrial starchy food wastes. Appl Energ 2014, 136:590-598.

This report evaluates the feasibility of bioconversion of starchy food waste (inedible dough, breadings, and batter liquid) into n-butanol through $\mathrm{ABE}$ fermentation. It demonstrates that industrial starchy food waste is a feasible alternative substrate for fermentative production of butanol

Figure captions

Figure 1: Food waste-based biorefinery

Figure 2: Bioproduction of chemical building blocks from food waste 
Tables

Table 1: Summary of bioproduction of chemicals from food waste*

\begin{tabular}{|c|c|c|c|c|c|c|c|}
\hline Chemical & Food waste & Microorganism & $\begin{array}{c}\text { Process } \\
\text { mode }\end{array}$ & $\begin{array}{l}\text { Titre } \\
\text { (g/L) }\end{array}$ & $\begin{array}{l}\text { Yield } \\
\text { (g/g) }\end{array}$ & $\begin{array}{c}\text { Productivity } \\
\text { (g/L. h) }\end{array}$ & Reference \\
\hline \multirow{4}{*}{ Succinic acid } & Cake waste & $\begin{array}{l}\text { Actinobacillus } \\
\text { succinogenes }\end{array}$ & Batch & 24.8 & 0.80 & 0.79 & [16] \\
\hline & $\begin{array}{l}\text { Pastry } \\
\text { waste }\end{array}$ & $\begin{array}{l}\text { Actinobacillus } \\
\text { succinogenes }\end{array}$ & Batch & 31.7 & 0.67 & 0.87 & [16] \\
\hline & Bread waste & $\begin{array}{l}\text { Actinobacillus } \\
\text { succinogenes }\end{array}$ & Batch & 47.3 & 1.16 & 1.12 & [17] \\
\hline & $\begin{array}{c}\text { Fruit and } \\
\text { vegetable } \\
\text { waste }\end{array}$ & $\begin{array}{l}\text { Yarrowia } \\
\text { lipolytica }\end{array}$ & $\begin{array}{l}\text { Fed- } \\
\text { batch }\end{array}$ & 140.6 & 0.47 & 0.43 & {$[18]$} \\
\hline \multirow{3}{*}{ Lactic acid } & $\begin{array}{l}\text { Mixed food } \\
\text { waste (rice, } \\
\text { noodles, } \\
\text { meat and } \\
\text { vegetables) }\end{array}$ & $\begin{array}{l}\text { Lactobacillus } \\
\text { casei Shirota }\end{array}$ & Batch & 94.0 & 0.94 & 2.61 & {$[20]$} \\
\hline & $\begin{array}{c}\text { Bakery } \\
\text { waste } \\
\text { (cakes, } \\
\text { breads and } \\
\text { pastries) }\end{array}$ & $\begin{array}{l}\text { Lactobacillus } \\
\text { casei Shirota }\end{array}$ & Batch & 82.6 & 0.94 & 2.50 & {$[20]$} \\
\hline & $\begin{array}{l}\text { Fruit waste } \\
\text { (plums, } \\
\text { apples and } \\
\text { pears) }\end{array}$ & $\begin{array}{l}\text { Enterobacter } \\
\text { ludwigii FMCC } \\
204\end{array}$ & $\begin{array}{l}\text { Fed- } \\
\text { batch }\end{array}$ & 50.1 & 0.40 & 0.41 & {$[22]$} \\
\hline
\end{tabular}




\begin{tabular}{|c|c|c|c|c|c|c|c|}
\hline 2,3-Butanediol & $\begin{array}{c}\text { Mixed } \\
\text { vegetable } \\
\text { waste with } \\
80 \% \\
\text { broccoli }\end{array}$ & $\begin{array}{l}\text { Enterobacter } \\
\text { ludwigii FMCC } \\
204\end{array}$ & $\begin{array}{l}\text { Fed- } \\
\text { batch }\end{array}$ & 17.6 & 0.32 & 0.39 & [22] \\
\hline \multirow[t]{2}{*}{ Ethanol } & $\begin{array}{c}\text { Mashed } \\
\text { potatoes, } \\
\text { sweet corn } \\
\text { and white } \\
\text { bread }\end{array}$ & $\begin{array}{c}\text { Saccharomyces } \\
\text { cerevisiae }\end{array}$ & Batch & 144.0 & 0.74 & 2.0 & [23] \\
\hline & $\begin{array}{l}\text { Bakery } \\
\text { waste }\end{array}$ & $\begin{array}{c}\text { Saccharomyces } \\
\text { cerevisiae }\end{array}$ & Batch & 58.0 & 0.50 & 1.82 & [24] \\
\hline \multirow{4}{*}{ n-Butanol } & $\begin{array}{c}\text { Mashed } \\
\text { potatoes, } \\
\text { sweet corn } \\
\text { and white } \\
\text { bread }\end{array}$ & $\begin{array}{c}\text { Clostridium } \\
\text { beijerinckii } \\
\text { P260 }\end{array}$ & Batch & $\begin{array}{c}12.3 \\
(18.9)\end{array}$ & $\begin{array}{c}0.25 \\
(0.38)\end{array}$ & $0.30(0.46)$ & [26] \\
\hline & $\begin{array}{l}\text { Inedible } \\
\text { dough }\end{array}$ & $\begin{array}{c}\text { Clostridium } \\
\text { beijerinckii } \\
\text { NCIMB } 8052\end{array}$ & Batch & $\begin{array}{c}9.3 \\
(14.4)\end{array}$ & $\begin{array}{c}0.24 \\
(0.37)\end{array}$ & $0.16(0.24)$ & [27] \\
\hline & Breading & $\begin{array}{c}\text { Clostridium } \\
\text { beijerinckii } \\
\text { NCIMB } 8052\end{array}$ & Batch & $\begin{array}{c}10.5 \\
(14.8)\end{array}$ & $\begin{array}{c}0.26 \\
(0.36)\end{array}$ & $0.14(0.20)$ & [27] \\
\hline & $\begin{array}{l}\text { Batter } \\
\text { liquid }\end{array}$ & $\begin{array}{c}\text { Clostridium } \\
\text { beijerinckii } \\
\text { NCIMB } 8052\end{array}$ & Batch & $\begin{array}{c}10.0 \\
(15.1)\end{array}$ & $\begin{array}{c}0.25 \\
(0.37)\end{array}$ & $0.21(0.31)$ & [27] \\
\hline
\end{tabular}

*The data within brackets refers to ABE (acetone + n-butanol + ethanol). 
Table 2: Yield of chemical building blocks on food waste*

\begin{tabular}{lcc}
\hline Metabolite & $\begin{array}{c}\text { Maximum theoretical } \\
\text { yield on glucose }\end{array}$ & $\begin{array}{c}\text { Maximum theoretical } \\
\text { yield on dry FW }\end{array}$ \\
& $(\mathbf{m o l} / \mathbf{m o l})$ & $\mathbf{g} / \mathbf{k g})$ \\
\hline Acetic acid & 3.0 & 331.2 \\
Ethanol & 2.0 & 169.3 \\
Lactic acid & 2.0 & 331.2 \\
Pyruvic acid & 2.4 & 388.6 \\
1,3-propanediol & 1.5 & 210.0 \\
3-hydroxypropionic acid & 2.0 & 331.2 \\
2,3-butanediol & 1.1 & 182.2 \\
Succinic acid & 1.7 & 369.4 \\
Fumaric acid & 2.0 & 427.2 \\
Malic acid & 2.0 & 493.5 \\
n-Butanol & 1.0 & 136.2 \\
Citric acid & 1.3 & 470.1 \\
\hline
\end{tabular}

*The calculations have been made using sugars concentration from FW hydrolysate reported in Pleissner et al. [14]. 


\section{Figures}

\section{Figure 1}

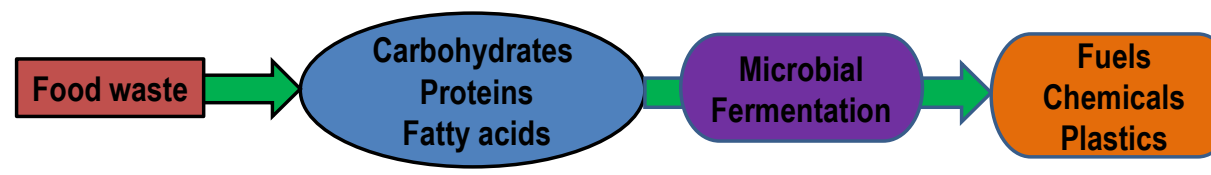

\section{Figure 2}

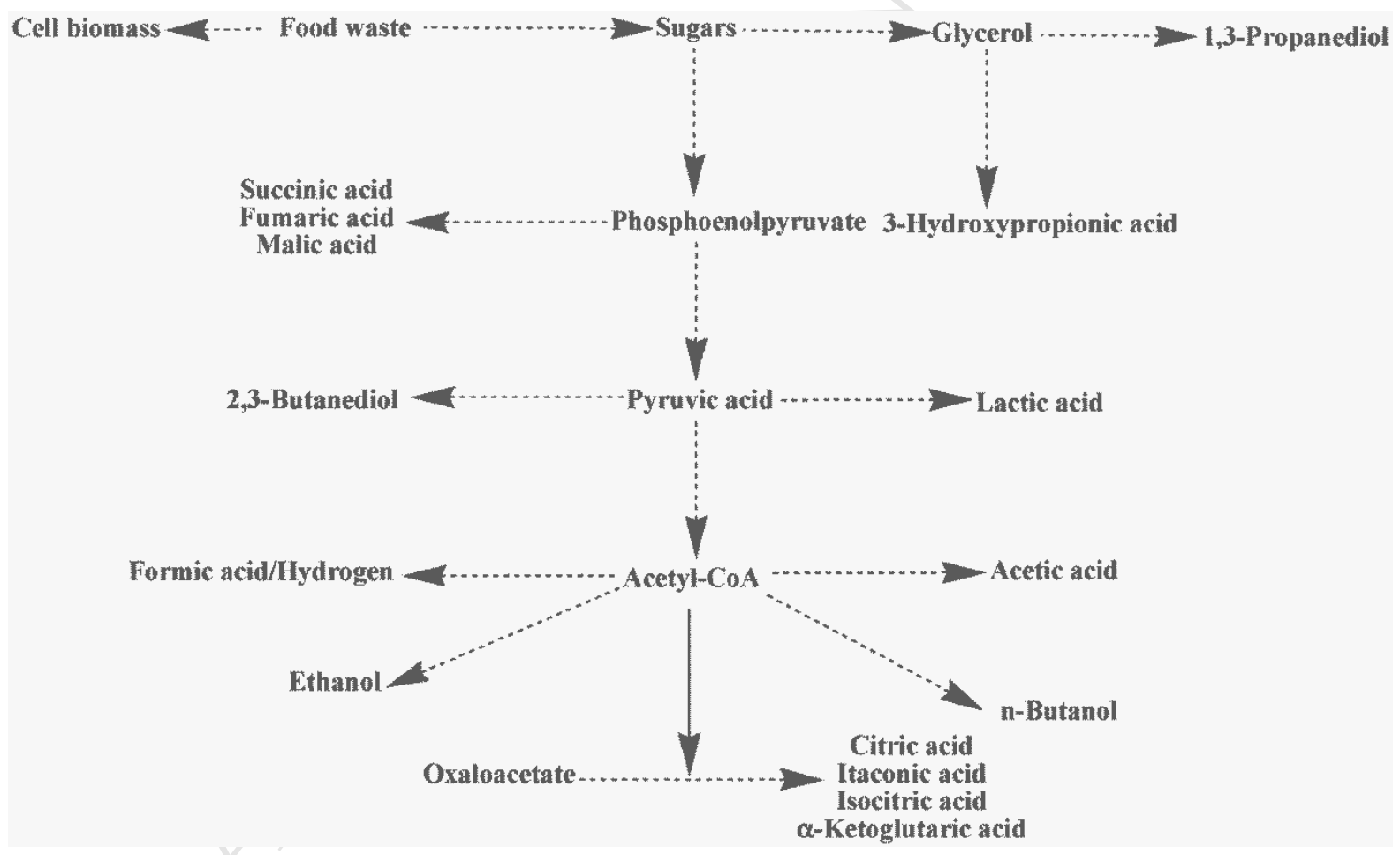

